\title{
LUTEINIZING HORMONE ACTIVITY IN BLOOD AND URINARY OESTROGEN EXCRETION BY THE SOW AT OESTRUS AND OVULATION
}

\author{
R. M. LIPTRAP AND J. I. RAESIDE \\ Department of Physiological Sciences, Ontario Veterinary College, Guelph, Canada
}

(Received 3rd November 1965)

\begin{abstract}
Summary. Luteinizing hormone ( $\mathrm{LH}$ ) activity in blood was assessed by the ovarian cholesterol depletion (OCD) method and oestrogens were estimated chemically in the urine of seven sows before and during oestrus. In three sows, peritoneal cannulation permitted the time of ovulation to be related to $\mathrm{LH}$ and oestrogen determinations. The findings suggest a marked elevation of blood LH activity coincident with a peak of urinary oestrogen excretion, and occurring 40 to $48 \mathrm{hr}$ before the time of ovulation.
\end{abstract}

\section{INTRODUCTION}

The view has been expressed that a surge of luteinizing hormone (LH) activity in the circulation is necessary to aid or trigger ovulation (Hisaw, 1947). Lozinski, Holden \& Macallum (1942) found evidence of gonadotrophic activity in the serum from one of two sows just before service. The sudden drop in gonadotrophic content of the pituitary gland of the sow at oestrus has been interpreted by Nalbandov (1953) as reflecting hormone release. Oestrogens, at least in part, may facilitate the release of ovulating hormone and the positive feedback effect of sex steroids has been summarized by Sawyer (1964). The pattern of urinary oestrogen excretion during the oestrous cycle in the sow has been determined recently by chemical methods (Velle, 1958; Raeside, 1961; Lunaas, 1962).

In an effort to define more clearly the relationship between luteinizing hormone and oestrogens, these hormones were estimated at frequent intervals in the sow before and during oestrus. Since ovulation is the most important event during oestrus, peritoneal cannulas were placed in several sows in order to relate the precise time of ovulation to the results of the hormone determinations.

\section{MATERIAL AND METHODS}

Mature sows of either the Landrace $\times$ Yorkshire cross or Landrace $\times$ Berkshire cross were used. All animals had farrowed at least one litter and had shown one, or more, normal oestrous cycles before urine and blood collections were commenced. 
Blood samples were collected from the anterior vena cava using the technique of Carle \& Dewhirst (1942). The samples were allowed to clot, then centrifuged, and the serum removed and stored at $4^{\circ} \mathrm{C}$ until the time of bio-assay, which was always performed within 6 days of the first blood collection. The ovarian cholesterol depletion method (Bell, Mukerji \& Loraine, 1964), with immature female Wistar rats obtained from Woodlyn Farms, Guelph, was used to assess luteinizing hormone activity of the blood. Each rat received a subcutaneous injection of 50 i.u. of pregnant mare serum (Equinex; Ayerst,

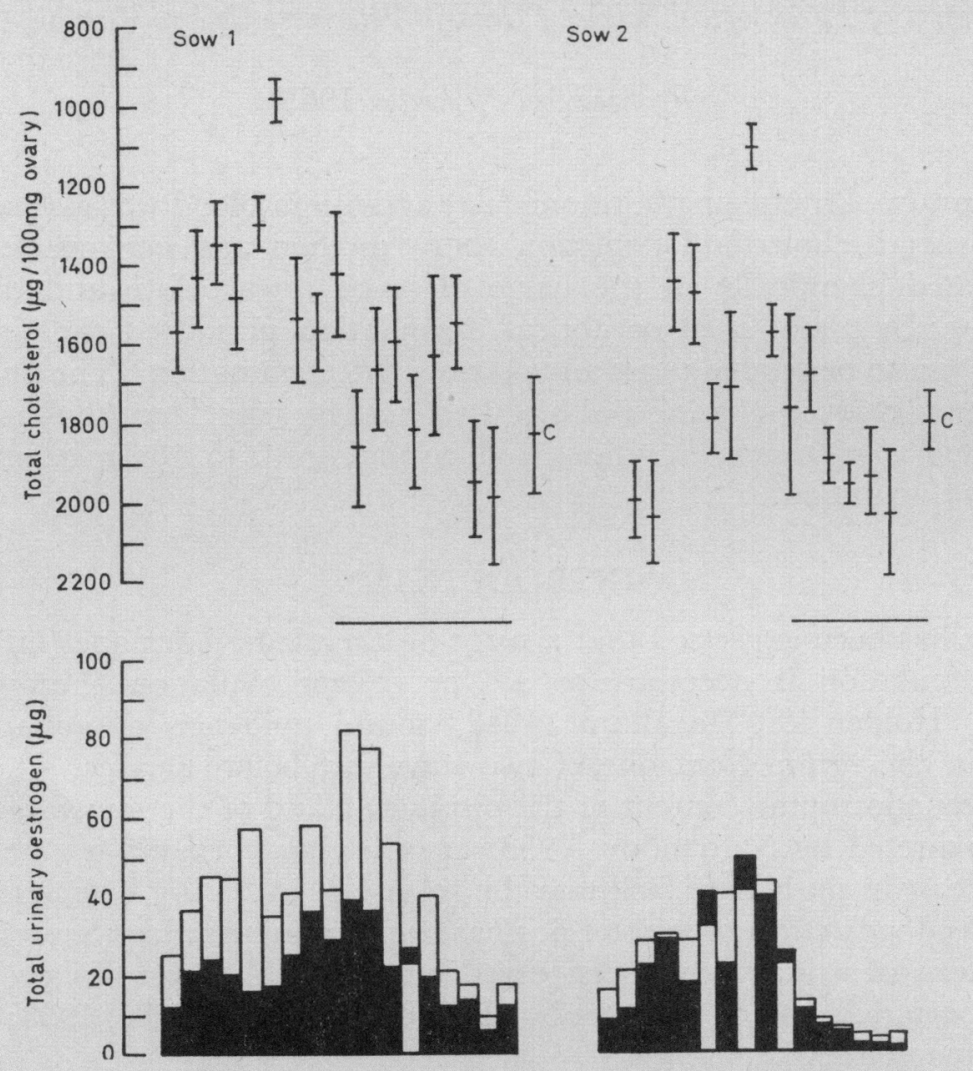

TEXT-FIG. 1. Luteinizing activity in serum and urinary excretion of total oestrogen in two sows at oestrus. Upper portion: vertical lines indicate standard error about mean total cholesterol in $100 \mathrm{mg}$ ovarian tissue, thus reflecting LH activity in $0.05 \mathrm{ml}$ of serum. C, Saline control. Oestrus is shown by horizontal bars. Lower portion: black, oestrogen concentration $(\mu \mathrm{g} / 1)$; white, amount $(\mu \mathrm{g} / 8 \mathrm{hr})$.

McKenna \& Harrison, Ltd) followed $72 \mathrm{hr}$ later by a subcutaneous injection of 25 i.u. of human chorionic gonadotrophin (APL; Ayerst, McKenna \& Harrison, Ltd). The test material was administered on the 11th day after injection of chorionic gonadotrophin, when the ovaries were heavily luteinized and weighed from 60 to $90 \mathrm{mg}$. The amount of serum injected intraperitoneally in each rat was $0.05 \mathrm{ml}$ diluted to $0.5 \mathrm{ml}$ with physiological saline, for all samples except from Sow 5 where $0.1 \mathrm{ml}$ of serum was employed after diluting to the same volume. Cholesterol determinations were made by the method of 
Searcy \& Bergquist (1960). Five test rats (ten ovaries) were used for each sample of serum. Analysis of variance was applied to the results.

Complete and continuous collection of urine was made by means of a selfretaining catheter (Foley type, size No. 30 ) in the bladder. With the sow confined in a farrowing crate, the catheter was attached by a length of vinyl plastic tubing ( 5 to $6 \mathrm{ft}$ ) to a large polyethylene bottle. Once daily, the catheter was disconnected from the plastic tubing to allow the bladder to be flushed

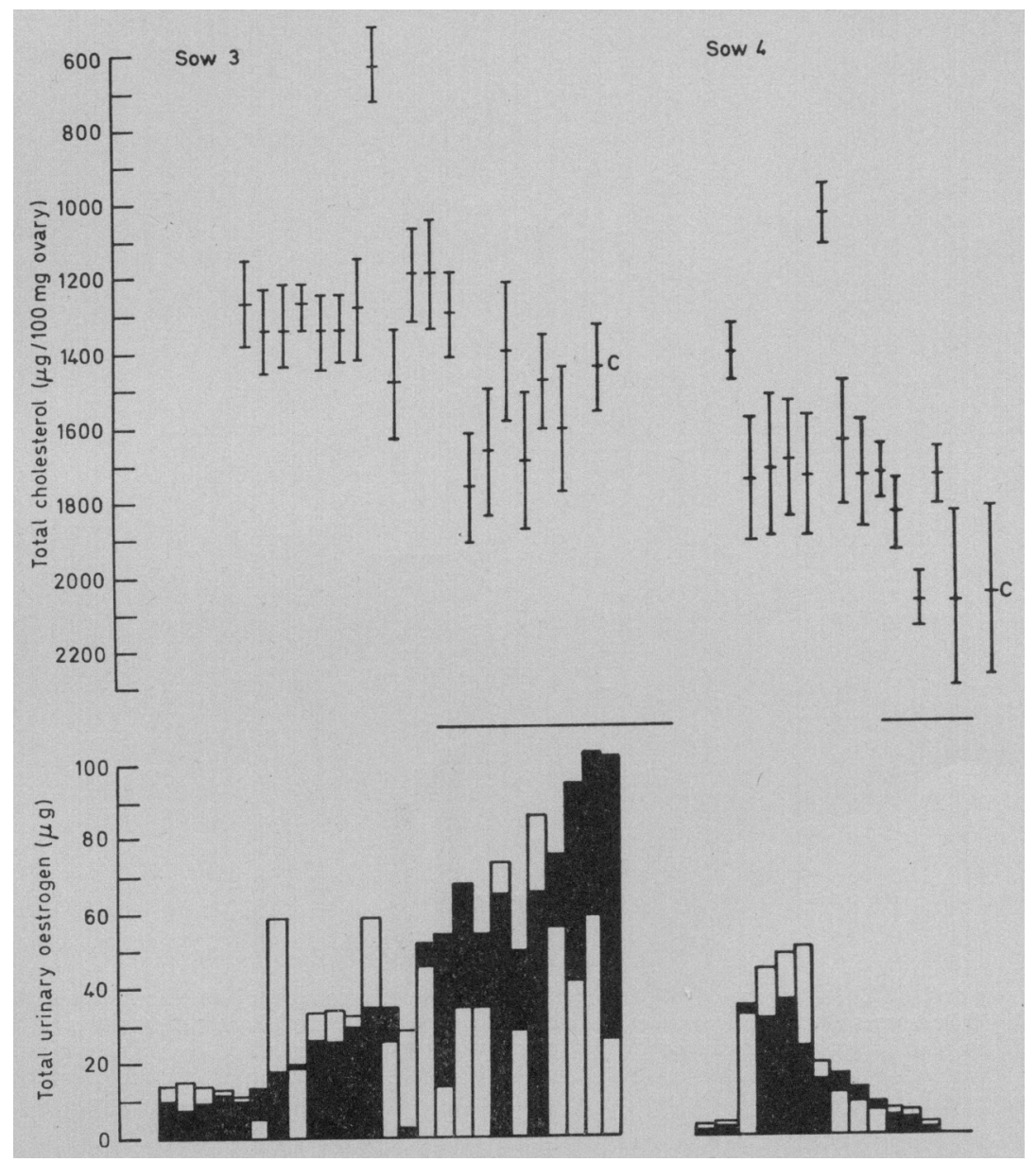

TEXT-FIG. 2. Luteinizing activity in serum and urinary excretion of total oestrogen in two sows at oestrus. Upper portion: vertical lines indicate standard error about mean total cholesterol in $100 \mathrm{mg}$ ovarian tissue, thus reflecting $\mathrm{LH}$ activity in $0.05 \mathrm{ml}$ of serum. C, Saline control. Oestrus is shown by horizontal bars. Lower portion: black, oestrogen concentration $(\mu \mathrm{g} / \mathrm{l})$; white, amount $(\mu \mathrm{g} / 8 \mathrm{hr})$.

with disinfectant solution ('Hibitane,' I.C.I. Ltd). The catheter was plugged while the sow was taken out of the crate for testing with the boar. The urine was removed at $08.00,16.00$ and 24.00 hours, and blood samples were taken at these times. The results of total oestrogen in the 8-hr urine samples were obtained with the procedure described by Raeside (1963a). 
In three sows, actual observation of the ovary through a peritoneal cannula permitted the timing of ovulation in relation to the onset of oestrus. A cannula of the type described by Betteridge \& Raeside (1962) was inserted into the left flank of the sow under pentobarbital sodium (Nembutal, Abbott Laboratories) anaesthesia. In Sows 6 and 7, ligatures were placed through the mesovarium of each ovary and fastened behind the inner flange of the cannula. To observe the ovary, a spay hook was used to pull the ovary by means of the

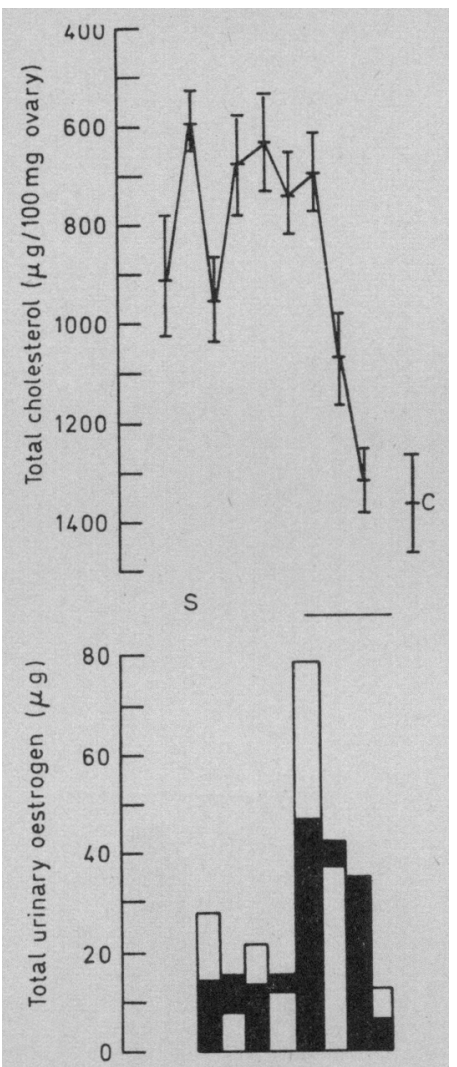

TEXT-FIG. 3. Luteinizing activity in serum and urinary excretion of total oestrogen in Sow 5 at oestrus with a peritoneal cannula. Upper portion: vertical lines indicate standard error about mean total cholesterol in $100 \mathrm{mg}$ ovarian tissue, thus reflecting LH activity in $0.10 \mathrm{ml}$ of serum. C, Saline control. Oestrus is shown by horizontal bar. S, Time of surgery. Lower portion: black, oestrogen concentration $(\mu \mathrm{g} / \mathrm{l})$; white, amount $(\mu \mathrm{g} / 8 \mathrm{hr})$.

ligature to a position near the cannula; after reflecting the ovarian bursa, the ovary could be observed with the aid of a dental mirror. In Sow 5, only the left ovary was handled during surgery and observations. The cannulas were removed from the sows 5 days after the end of oestrus and the ovaries removed for careful examination to confirm the earlier observations made in situ.

\section{RESULTS}

The pattern of urinary oestrogen excretion before and during oestrus is shown in Text-figs. 1 and 2. A well defined peak occurred near the onset of heat in 
Sows 1,2 and 4, followed by a relatively sudden fall to very low levels. The pattern is somewhat atypical in Sow 3 , but a suspected bladder infection may have been responsible for the erratic urine volumes collected. The luteinizing activity of the blood, as reflected by the ovarian cholesterol depletion in the test rats, indicates a brief but statistically significant $(P<0 \cdot 01)$ elevation 16 to $24 \mathrm{hr}$ before the onset of psychic oestrus (i.e. when fully receptive to the boar) in all four sows.

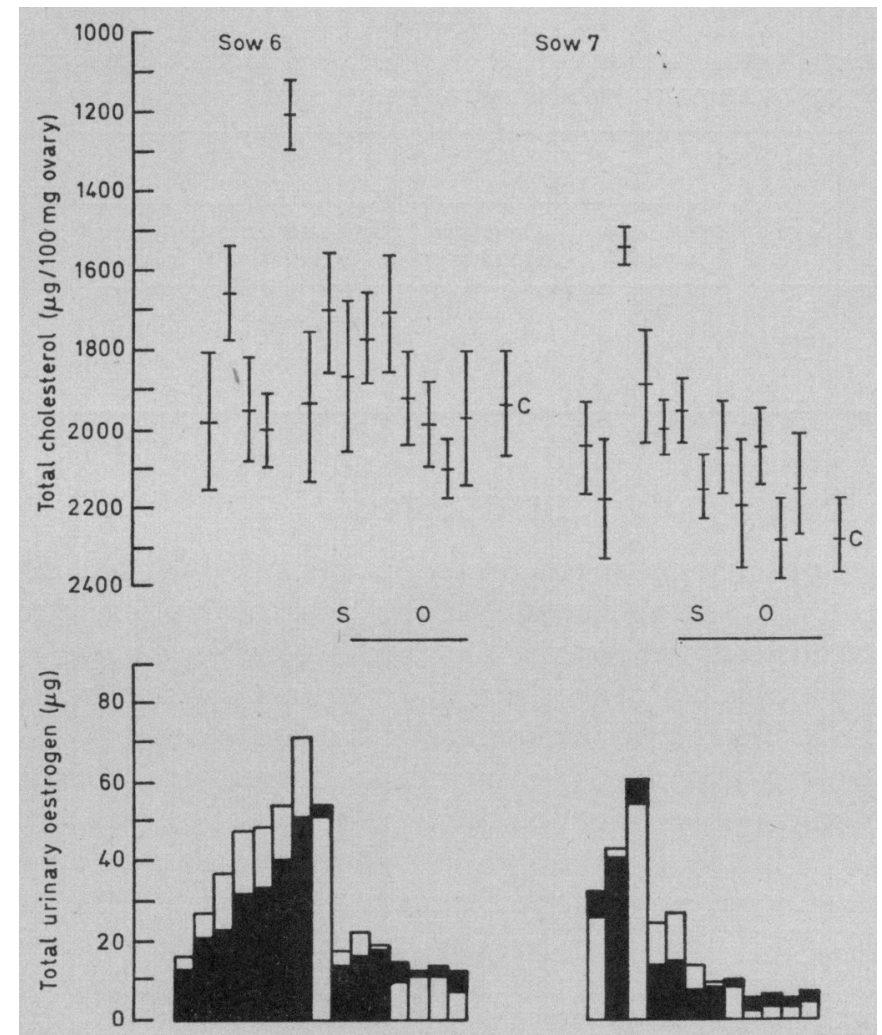

Text-rig. 4. Luteinizing activity in serum and urinary excretion of total oestrogen in two sows at oestrus with peritoneal cannulas. Upper portion: vertical lines indicate standard error about mean total cholesterol in $100 \mathrm{mg}$ ovarian tissue, thus reflecting LH activity in $0.05 \mathrm{ml}$ of serum. $\mathrm{C}$, Saline control. Oestrus is shown by horizontal bars. S, Time of surgery; $O$, Time of ovulation. Lower portion: black, oestrogen concentration $(\mu \mathrm{g} / \mathrm{l})$; white, amount $(\mu \mathrm{g} / 8 \mathrm{hr})$.

In Sow 5 (Text-fig. 3), where surgical implantation of the peritoneal cannula was performed $36 \mathrm{hr}$ before oestrus, the total urinary oestrogen pattern is similar to the other sows. However, the luteinizing activity of the blood dropped after surgery instead of rising to a peak, and ovulation was not observed in the accessible ovary. Ovulation did not occur in the contralateral ovary either, as evidenced by the lack of corpora lutea formation when both ovaries were removed and examined 5 days later. When surgery was performed at the onset of oestrus in Sows 6 and 7, the brief and statistically significant elevation in luteinizing activity had already occurred. The time of ovulation relative to 
oestrus, LH activity and oestrogen production is shown in Text-fig. 4. It is evident that the urinary excretion of oestrogen of these two sows is similar to that of the other sows and that the peak occurred about $40 \mathrm{hr}$ before the time of ovulation.

The number of corpora lutea formed and the number of unruptured follicles remaining, as determined at the time of ovariectomy 5 days after oestrus, are given in Table 1.

TABLE 1

DATA FROM EXAMINATION AT 5 DAYS AFTER OESTRUS OF OVARIES FROM SOWS WITH PERITONEAL GANNULAE

\begin{tabular}{c|c|c|c|c}
\hline \multirow{3}{*}{ Sow } & \multicolumn{2}{|c|}{ Right ovary } & \multicolumn{2}{c}{ Left ovary } \\
\cline { 2 - 3 } \cline { 5 - 6 } & $\begin{array}{c}\text { Corpora lutea } \\
\text { formed }\end{array}$ & $\begin{array}{c}\text { Unruptured } \\
\text { follicles }\end{array}$ & $\begin{array}{c}\text { Corpora lutea } \\
\text { formed }\end{array}$ & $\begin{array}{c}\text { Unruptured } \\
\text { follicles }\end{array}$ \\
\hline 5 & 0 & 10 & 0 & 11 \\
6 & 10 & 1 & 3 & 6 \\
7 & 3 & 1 & 6 & 3 \\
\hline
\end{tabular}

\section{DISGUSSION}

The pattern of urinary oestrogen excretion is similar to that described previously by Velle (1958) and Raeside (1963b); the peak of excretion occurring just before or at the onset of oestrus. The results from Sows 6 and 7 suggest that urinary oestrogens reach a peak about $40 \mathrm{hr}$ prior to ovulation.

The brief rise in blood luteinizing activity appears to occur 16 to $24 \mathrm{hr}$ before the onset of oestrus and thus is coincident with maximal urinary oestrogen excretion. In the two sows in which the time of ovulation was determined this elevation in LH occurred about 40 to $48 \mathrm{hr}$ before ovulation. Presumably this represents the ovulatory surge of $\mathrm{LH}$. Ramirez \& McCann (1964) and Schwartz \& Caldarelli (1965), using the ovarian ascorbic acid depletion method, detected a peak of $\mathrm{LH}$ activity in plasma on the day of pro-oestrus in the rat. Tanabe, Warnick, Casida \& Grummer (1949) found that ovulation in sows occurred 36 to $48 \mathrm{hr}$ after an intravenous injection of sheep pituitary extract, whether administered on the 6 th, 17 th or 20th day of the oestrous cycle. Similarly, Dziuk \& Baker (1962), after controlling the onset of follicular growth in sows by feeding an oral progestagen, obtained ovulation in $94 \%$ of animals $40 \mathrm{hr}$ after the injection of 250 to 2000 i.u. of human chorionic gonadotrophin. These time intervals are similar to those between the peak of $\mathrm{LH}$ and the time of ovulation determined in the present study.

The results for Sow 5 suggest that the failure of ovulation was possibly due to the absence of the peak in LH activity seen in the other sows. The inter- ference with the proper release of $\mathrm{LH}$ may have been due to anaesthesia at this critical time. Everett \& Sawyer (1950) were able to block ovulation in the rat by injecting pentobarbital sodium at the proper time during pro-oestrus.

The within-group variation (standard error) for the detection of $\mathrm{LH}$ is too large to illustrate clearly the rise and fall of luteinizing activity. Since the 
serum samples were taken at $8-\mathrm{hr}$ intervals it is not possible to estimate the duration of the elevation in LH activity, apart from indicating that it must be only a matter of hours. Nalbandov (1961) has suggested that the effect of LH is a transient one with respect to ovulation and the time of its release from the pituitary is brief.

The correlation of the peaks in $\mathrm{LH}$ activity and urinary oestrogen levels lends support to the idea that the ovulatory surge in LH may be caused by the stimulatory action of oestrogen, or oestrogen plus a small amount of progesterone, secreted by the follicle before ovulation (McGann 1963). Knowledge of the mechanism whereby gonadal hormones regulate the discharge of FSH and LH in the normal cycle has been outlined by Flérko (1963). On the basis of the present study it would appear that the sow is an experimental animal well-suited to investigations of hypophysial-gonadal relationships.

\section{ACKNOWLEDGMENTS}

The authors wish to express thanks to Dr C. Chappel (formerly of Ayerst, McKenna \& Harrison, Ltd) for the gifts of gonadotrophin used to prime the rats; and to Dr H. G. Downie for assistance and advice with the surgery. The assistance of Mrs A. Burnett and Mr D. Telford is gratefully acknowledged.

This work was supported in part by a grant from the National Research Council of Canada.

\section{REFERENCES}

Bell, E. T., MukerjI, S. \& Loraine, J. A. (1964) A new bioassay method for luteinizing hormone depending on the depletion of rat ovarian cholesterol. J. Endocr. 28, 321.

Bettermge, K. J. \& Raeside, J. I. (1962) Observation of the ovary by peritoneal cannulation in pigs. Res. vet. Sci. 3, 390.

Carle, B. N. \& Dewhirst, W. H. Jr. (1942) A method for bleeding swine. F. Am. vet. med. Ass. 101, 495.

DzIuk, P. J. \& BAKER, R. D. (1962) Induction and control of ovulation in swine. F. Anim. Sci. 21, 697.

EVERETT, J. W. \& SAWYER, C. H. (1950) A 24-hour periodicity in the 'LH-release apparatus' of female rats, disclosed by barbiturate sedation. Endocrinology, 47, 198.

FLÉRKo, B. (1963) The central nervous system and the secretion and release of luteinizing hormone and follicle stimulating hormone. Advances in Neuroendocrinology, p. 211. Ed. A. V. Nalbandov. University of Illinois Press, Urbana.

Hisaw, F, L. (1947) Development of the graafian follicle and ovulation. Physiol. Rev. 27, 95.

LozINSkr, E., Holden, G. W. \& MACALLUM, E. N. (1942) On the excretion of oestrogens and gonadotropic hormone in the urine and concentration of gonadotropic hormone in the serum of the pregnant sow. Rev. Can. Biol. 1, 677.

LunAas, T. (1962) Urinary oestrogen levels in the sow during oestrous cycle and early pregnancy. J. Reprod. Fert. 4, 13.

MCCANN, S. M. (1963) Recent studies on the regulation of hypophysial luteinizing hormone secretion. Am. . . Med. 34, 379.

NALBANDOv, A. V. (1953) Gonadotrophic activity of pituitary glands and the induction of ovulation. Iowa St. Coll. F. Sci. 28, 45.

Nalbandov, A. V. (1961) Mechanisms controlling ovulation of avian and mammalian follicles. Control of Ovulation, p. 122. Ed. C. A. Villee. Pergamon Press, New York.

RAESiDE, J. I. (1961) A chemical estimation of urinary oestrogens during the oestrous cycle in the pig. Prov. IVth int. Congr. anim. Reprod., The Hague, p. 355.

RAEstoE, J. I. (1963a) A procedure for the chemical determination of estrone and estradiol-17 $\beta$ in the urine of nonpregnant sows. Can. F. Biochem. Physiol. 41, 2013.

RAESIDE, J. I. (1963b) Urinary oestrogen excretion in the pig at oestrus and during the oestrous cycle. 7. Reprod. Fert. 6, 421.

RamiRez, V. D. \& McGANN, S. M. (1964) Fluctuations in plasma luteinizing hormone concentrations during the estrous cycle of the rat. Endocrinology, 74,814 . 
SAWYER, C. H. (1964) Control of secretion of gonadotropins. Gonadotropins: Their Chemical and Biological Properties and Secretory Control, p. 113. Ed. H. H. Cole. Freeman, San Francisco.

Schwartz, N. B. \& Caldarelli, D. (1965) Plasma ly in cyclic female rats. Proc. Soc. exp. Biol. Med. $119,16$.

SEARCY, R. L. \& BERGQUIST, L. M. (1960) A new color reaction for the quantitation of serum cholesterol. Clin. chim. Acta, 5, 192.

Tanabe, T. Y., Warnick, A. C., Casida, L. E. \& Grummer, R. H. (1949) The effects of gonadotrophins administered to sows and gilts during different stages of the estrual cycle. $\mathcal{F}$. Anim. Sci. 8, 550.

VELLE, W. (1958) Undersekelser over naturlig forekommende ostrogener hos drevtyggere og gris. Thesis, Oslo. 